\title{
Building up a convenient accountability: How the 'anti-corruption' law in Brazil was put into force
}

Fernanda Odilla Vasconcellos de Figueiredo

Brazil has not only experienced a new and relatively high growth cycle but also several corruption scandals occurring one after another since the end of the military rule in 1985. As a result of both internal and external demands, the country has implemented a new set of anti-corruption norms, procedures and punishments mainly in the Federal sphere. However, these efforts do not necessarily mean less corruption in the short term, nor increased accountability.

This paper looks at the Brazilian legal instrument that makes companies strictly liable for domestic and international corrupt acts and provides civil and administrative sanctions such as monetary fines and widespread announcements of any condemnatory decision through the Brazilian Clean Company Act (Law 12846/2013). The aim here is to question the extent to which Brazil complies with international anti-corruption legislation by analysing the domestic implementation and enforcement of its new Clean Company Act (CCA).

The Brazilian Act was dubbed an 'Anti-Corruption Law' despite the fact that the word 'corruption' appears in its text only once when it quotes the name of OECD Convention on Combating Bribery of Foreign Public Officials in International Business Transactions (1997). In the Portuguese translation, the word 'bribery' was changed to 'corruption'. Indeed, the Brazilian Law expanded its concept of bribery, referring to it generally as 'acts against the public administration, national or foreign'. The written Law, in Chapter 2, also lists five specific topics to frame the legal concept of corruption, which includes offers, promises, or actual giving of any undue pecuniary or other 
advantage as well as financing illegal acts and hindering or interfering with investigations. The Act was put into force to guarantee administrative punishment for companies that are involved in domestic and international bribery. Thus, its focus is on corporations, not individuals (De Figueiredo 2016).

The data used here includes all the versions of the bill as well as messages and reports signed by politicians explaining how the Law was designed and changed. Campaign financing records, especially donations made by companies that are, since the beginning of 2014, under investigation in a massive corruption scandal, are also used in this paper. These data help to explain how Brazil put into force Law 12846/2013 and might also be seen as evidence to support the concept of 'convenient accountability', which is introduced here as the main framework to understand this case study.

Accountability by definition carries out two main connotations that embrace the efforts of exercising power: answerability and enforcement (Schedler 1999). Indeed, it needs both the obligation of public officials - politicians and civil servants - to explain and report what and why they are doing as well as the capacity of public agencies which impose sanctions on rulers, enforcers or powerholders who misused the public office for private gains. However, accountability is still considered as a relatively 'underexplored concept whose meaning remains evasive, whose boundaries are fuzzy, and whose internal structure is confusing' (Schedler 1999:13). Here, there is room to explore its different facets.

According to O'Donnell (1998, 1999), accountability runs not only vertically, 'making elected officials answerable to the ballot box' as well as controlled by the media and civil society as a whole, but also horizontally, across a network of state agencies and institutions that 'can call into question, and eventually punish, improper ways of discharging the responsibilities of a given office' (O'Donnell 1999: 165). However, at the 
same time, both horizontal and vertical accountability can be limited or even inefficient. It happens - sometimes deliberately and entirely for convenience depending on the enforcer - with the development of less risky and less costly horizontal checks and balances systems in order to attend different demands and pressures.

In other words, anti-corruption mechanisms can be conveniently designed and enforced to fit different kinds of demands from both those who want and do not want greater accountability. The concept of rationality implies, to some extent, conscious reactions not only to commit a criminal or corrupt act but to also prevent it. The main argument of this paper is that when calculating costs and benefits, enforcers might often choose the 'convenient accountability' to keep a certain balance to abstain from 'whatever it costs' behaviour, which is potentially damaging for politicians in office.

In the first section of this paper, the process to design and put into force the new piece of legislation against international and domestic bribery that took around 15 years to establish in Brazil will be presented. This process culminated in the publication of enforcement guidelines in March 2015 and in the issue of the provisional Executive Order No. $703^{1}$ in December 2015 reviewing some important topics, especially to attend part of the demand coming from the prosecutor service and the account court as well as corporations.

The role of external drivers within this process, such as people on the streets in massive anti-corruption demonstrations, the media covering a different range of corruption scandals as well as the major government contractors and campaign donors who can be potential targets of this Law acting on the backstage will also be explored. The second section briefly compares the Brazilian Act with the main provisions of the UK Bribery Act and the US FCPA (Foreign Corrupt Practices Act) as well as the

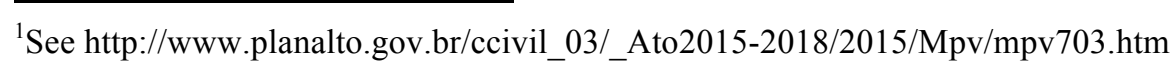

3RASILIANA- Journal for Brazilian Studies. Vol. 4, n.2 (2016). ISSN 2245-4373. 
Organization for Economic Cooperation and Development's (OECD) main guidelines in order to answer whether Brazil follows international patterns. Finally, and before final thoughts on how Brazil could better enforce its anti-corruption law, it will be discussed whether there is enough evidence to suggest that the concept of 'convenient accountability' fits to explain this process as well as to put the Brazilian CCA into practice.

Few scholars from Political and Social Sciences have written about this new legislation, which has left the most robust analysis until now to practitioners, especially those in the field of Law who have been discussing the concept of automatic and objective responsibility (Magalhães 2013; Bottini and Tamasauskas 2014; Nascimento 2014), or those comparing the main points of the Brazilian CCA with the UK Bribery Act as well as the US FCPA or even the OECD Convention (Levine et al 2013; Zaheer 2014). This paper may fill in this gap not only by pointing out the major provisions and achievements of this new Brazilian Law but also by shedding light onto the importance and nuances of its process through the eyes of Political and Social Sciences.

In sum, this paper shows that the way anti-corruption laws are designed and put into force might affect their enforcement, especially in countries such as Brazil where 'convenient accountability' applies in certain circumstances; or, in other words, where political will is affected by the inevitable pressure of those who do not want greater control mechanisms. Hence, understanding how accountability is imposed could be very useful in the process of enhancing accountability.

\section{Step by step: Being pushed by external drivers}

The backbone of the process of creating and putting the Brazilian CCA into force can be 
compared to one of the laws of motion, more precisely to Newton's Third Law: 'For every action there must be an equal and opposite reaction' (Newton 1999:19). The Brazilian legislators were, to some extent, pushed forwards and backwards during the whole process. The 'anti-corruption law' timeline therefore helps to visualize this tension among different kinds of demands provoking action-reaction behaviour from 2000 until now.

Although it took 15 years for Brazil to design, enact and put into effect its antiinternational bribery law, there is evidence that every single step forward within this process was pushed by a strong claim from the international anti-corruption organizations as much as the national civil society and, sometimes, even by specific corruption scandals intensively covered by the national media. At the same time, the apparent lack of rush in improving this piece of anti-corruption legislation may be connected to the demands from those who do not want greater accountability, especially the potential targets of this Law - companies who are massive campaign financers and governmental contractors.

In 2000, Brazil signed the OECD Convention on Combating Bribery of Foreign Public Officials in International Business Transactions, which was enacted three years before. Even as one of the non-OECD members, Brazil committed to ensuring that its national parliament approve the Convention and pass legislation necessary for its ratification and implementation into national law. For almost ten years, however, nothing in this direction has been made and the OECD had criticized Brazil for not holding corporate entities liable for corrupt conduct. After the UK Anti Bribery Act (2010), Brazil lost its excuse that even developed countries had not passed a similar statute.

Before designing its CCA, it is important to point out that Brazil first included 
new provisions on its Penal Code to punish private parties in cases of crimes against public administration as well as changed some points of a specific law against money laundering. Notwithstanding, it was not considered enough by the international anticorruption community. It was only in February 2010, under intense international pressures (Nascimento 2014), mainly from the OECD, that the Federal Executive branch finally sent its first version of the CCA to be analysed and voted by its National Congress $^{2}$. Among the reasons listed in the statement that was sent to the Congress, the federal Execute highlighted not only the gap in the Brazilian legislation to punish companies involved in international corruption cases but also the necessity to cooperate with the OECD Convention as well as the United Nations Convention Against Corruption (2005) and the Inter-America Convention Against Corruption (1996) ${ }^{3}$.

The Brazilian bill was mainly designed by the Comptroller General Office (CGU in Portuguese), the internal anti-corruption agency within the Federal Executive branch, with the help of the Federal Government Attorney General's Office ${ }^{4}$ as well as the Ministry of Justice. The three ministers of cabinet signed the statement to the National Congress stressing that such a piece of legislation be considered 'urgent'. The heads of the Comptroller General Office and the Federal Government Attorney General's Office as well as the minister of Justice claimed that civil and administrative punishments were better than criminal ones in the case of corporations because they are faster and more

\footnotetext{
${ }^{2}$ In Brazil, the Congress has a Chamber of Deputies (lower house with 513 members on four-year terms) and a Senate (upper house with 81 members on eight-year terms). Both houses have to approve the same bill text before it goes for the presidential enactment.

${ }^{3}$ For the original statement text, access: http://www.camara.gov.br/proposicoesWeb/prop_mostrarintegra?codteor $=735505 \&$ filename $=$ MSC $+52 / 2010+\% 3 \mathrm{D}$ $\% 3 \mathrm{E}+\mathrm{PL}+6826 / 2010$

${ }^{4}$ In Brazil, the heads of Comptroller General Office and the Federal Attorney General have the status of minister of cabinet.
} 
efficient. The bill, as well as this message, was sent to Congress eight months before the 2010 federal elections, when President Lula used his popularity to build up the former minister and, to some extent, the political novice, Dilma Rousseff, his successor. If the bill was approved on time, it would have been an important campaign flag for boosting Dilma's image. In addition, the bill arrived in Congress at the same moment Brazil was experiencing a massive corruption scandal. Hence, the decision to send the bill can be seen, in the very least, as good timing to address corruption with stronger measures.

At that time, the governor of the Distrito Federal had been accused of leading a scheme which consisted of overcharging contracts with private companies in order to inject money into political parties and politicians. Mr José Roberto Arruda was the only governor affiliated to DEM (an opposing party to the federal administration ran by President Lula) and the Federal Police arrested him three days after President Lula signed the bill. The case received national media attention because a whistle-blower had recorded videos of the exact moment the money was delivered to Arruda's hands as well as to the hands of local politicians, businessmen and journalists. Some of them were shown hiding the bribery in their underwear, socks and bags.

When the Federal Executive branch designed the anti-corruption law, however, the aim was not to react to this specific scandal, although the timing was convenient. Lula's administration's main goal was using the company's assets as compensation for the damage caused by corrupt acts (Falcão 2010). As the Comptroller General Office head chief stated at that time, it was the first time Brazil would have a piece of law to support seizing a certain company's revenue capital to seek compensation for the losses actually caused by corruption. In turn, the National Congress pushed a tenfold increase in the maximum fine compared to the first version of the bill (De Figueiredo 2016).

It was only in May 2011 that the members of the Lower Chamber started to 
discuss the bill, creating a special commission to organize hearings and to analyse suggestions of changes and amendments from both congressional members and organized civil society. That month, the president's right-hand man and Chief of Staff, Mr Antonio Palocci, was under attack and under suspicion because of his own revenues. The case was brought to the attention of the public eye by the media. When Mr Antonio Palocci was a federal congressman, between 2006 and 2010, his personal wealth increased 20-fold. Although he said it was a result of consultancy work, he refused to give details of who paid him, or for what, on the grounds of client confidentiality. He resigned from his position of Chief of Staff after strong media coverage of the case. Until today, all the companies who paid him are still unknown. The scandal helped create the special commission to analyse the bill.

Notwithstanding, it was only in October 2011, five months after its creation, that the commission was put into force and a member of the Congress was appointed to rewrite the bill. The Brazilian Congress members who were appointed to be part of this special commission debated the bill for one year. One member, Mr. Eduardo Cunha, who was elected in 2015 as the president of the Lower Chamber by his own peers and later suspended by the Supreme Court under corruption accusations, offered a substitutive text for the bill in June 2012. After that, no formal step towards its approval, or even its rejection, was taken until April 2013.

It is important to highlight that 2012 was the year of local elections in all of Brazil's 5,567 municipalities $^{5}$. Besides the fact that some members of Congress traditionally run for these elections, most of them have strong political links to municipalities in their home states. Candidates must be registered by July 2012 and only

\footnotetext{
${ }^{5}$ In 2013 Brazil added three new municipalities. Since then the total is 5.670, according to IBGE (Instituto Brasileiro de Geografia e Estatística).
}

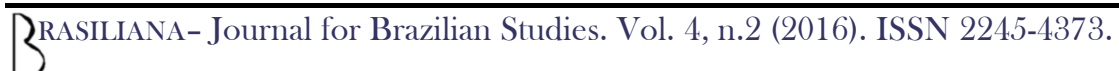


De Figueiredo, Fernanda Odilla Vasconcellos. Building up a convenient accountability: How the 'anti-corruption' law in Brazil was put into force.

then official campaign financing can start for the October elections. In 2012, all candidates running for mayor and local council representatives received a total of $\$ 0.9 \mathrm{bi}$ (or 1,867,590,018.37 reais) donated by private companies, most of them traditional campaign financers. As Table 1 shows, the top 15 financers, ranked by the total amount donated, were responsible for $22.6 \%$ of all donations made by companies in the 2012 elections (Política Aberta 2013) to all candidates from all parties who ran for office that year. At least six of these companies are now being investigated in another massive corruption scandal in Brazil, as will be discussed.

Table 1 - The 15 biggest companies' donations during 2012 elections in Brazil

\begin{tabular}{|c|c|c|c|}
\hline Companies & $\begin{array}{l}\text { Number of } \\
\text { donations }\end{array}$ & $\begin{array}{l}\text { Value (BRL } \\
\text { currency) }\end{array}$ & US dollar* \\
\hline 1. CONSTRUTORA ANDRADE GUTIERREZ SA & 133 & $81,165,800$ & $40,786,834.17$ \\
\hline 2. CONSTRUTORA QUEIROZ GALVAO S A & 107 & $52,135,000$ & $26,198,492.46$ \\
\hline 3. CONSTRUTORA OAS S.A. & 153 & $44,090,000$ & $22,155,778.89$ \\
\hline $\begin{array}{l}\text { 4. CONSTRUCOES E COMERCIO CAMARGO CORREA } \\
\text { S/A }\end{array}$ & 37 & $32,990,000$ & $16,577,889.44$ \\
\hline 5. VALE FERTILIZANTES S.A. & 29 & $30,470,000$ & $15,311,557.78$ \\
\hline 6. E.V. TEIXEIRA & 1 & $28,500,009.08$ & $14,321,612.60$ \\
\hline 7. BANCO BMG SA & 207 & $24,008,000$ & $12,064,321.60$ \\
\hline $\begin{array}{l}\text { 8. } \quad \text { PRAIAMAR INDUSTRIA } \\
\text { DISTRIBUICAO LTDA }\end{array}$ & 49 & $22,410,000$ & $11,261,306.5$ \\
\hline 9. JBS S/A & 25 & $20,210,000$ & $10,155,778.89$ \\
\hline 10. CONSTRUTORA NORBERTO ODEBRECHT & 23 & $19,450,000$ & $9,773,869.34$ \\
\hline 11. U T C ENGENHARIA S/A & 227 & $17,973,149$ & $9,031,733.16$ \\
\hline $\begin{array}{l}\text { 12. CARIOCA CHRISTIANI NIELSEN ENGENHARIA S } \\
\text { A }\end{array}$ & 53 & $15,282,000$ & $7,679,396.98$ \\
\hline 13. GALVAO ENGENHARIA S/A & 50 & $11,697,000.08$ & $5,877,889.48$ \\
\hline 14. CONTAX S.A. & 25 & $11,495,000$ & $5,776,381.9$ \\
\hline 15. BANCO ALVORADA S.A. & 38 & $10,250,000.02$ & $5,150,753.77$ \\
\hline
\end{tabular}

Sources: TSE/Politica Aberta.org (http://www.politicaaberta.org/doadores)

${ }^{*}$ Dollar exchange rate in January 2013: US\$ $1=\mathrm{R} \$ 1.99$

$\mathrm{B}^{\text {RASILIANA- Journal for Brazilian Studies. Vol. 4, n.2 (2016). ISSN 2245-4373. }}$ 
It was only in April 2013 that the bill started moving around again within Congress. At that time, the congressional member in charge of giving the final version of the bill formally admitted that companies were pushing for changes ${ }^{6}$. In one of his reports, Carlos Zarattini (Workers Party-São Paulo) stated that 'there was resistance from various business sectors' towards the new legal provision regarding joint liabilities. The current understanding is that the new legislation allows punishing not only the company that allegedly engaged in corruption but also parent, subsidiary, or affiliated companies that are part of a same group that benefited from the corrupt act, although the fine will be based on the gross revenues of the company to which the corrupt entity or subsidiary is directly linked, and not on the revenues of the group as a whole.

The bill was approved by the special commission and, at the beginning of June 2013, sent to a permanent commission in order to analyse whether it fit within the current Constitution of Brazil and finally, to transform it into Law, although there was no previous deadline defined for these steps.

In June 2013, however, Brazil saw massive street demonstrations across the country. Thousands of people in different cities protested for better services, new laws and less corruption in a movement that might be seen as both the expression of traditional middle class complaining with several aspects of national reality as well as of new proletariats who suffer from low pay, high turnover and poor working conditions (Singer 2013). In a clear response to the wave of what was called the 'June demonstrations', the Brazilian Congress did what it had not done in years in less than

\footnotetext{
${ }^{6}$ For the original report, highlighting the 'resistance', access page 4:

http://www.camara.gov.br/proposicoesWeb/prop_mostrarintegra?codteor $=1080299 \&$ filename $=$ TramitacaoPL+6826/2010
}

RRASILIANA- Journal for Brazilian Studies. Vol. 4, n.2 (2016). ISSN 2245-4373. 
one month. The bill passed in the Lower House on June 11th and in the Senate on July 5th; in the Senate, the processing was even faster. Overall, the bill that had been in the Lower House for approximately three years was approved by the Senate in just 16 days.

Both international and national demands forced the Senate to approve the new legislation. The bill was included on the list prepared by the president of the Senate to address part of people's demands during street protests (Senado 2013). In addition, while presenting his report to his peers, Senator Ricardo Ferraço (The Brazilian Democratic Movement Party - Espírito Santo) said that the text not only improved the Brazilian image in the international arena but also addressed the OECD's recommendations just before its fourth evaluation phase.

Also, to respond to people's demands presented in the street demonstrations, President Dilma Rousseff enacted the bill on August 1st. She exercised her authority to veto barring three provisions (Zaheer 2014). The major veto regards to the need to prove negligence or wilfully corrupt conduct. It deleted any fault or intent requirement from the Law for it to be enforced. Therefore, punishment would be applied based on evidence, facts and outcomes that any employee's act has somehow beneficiated the company as a consequence of a corrupt act. She also vetoed an item that limited the fine to the value of the contract between the company and the public agency and another item that took into consideration the extent to which a public official contributed to the illegal conduct to define the sanctions.

Despite the fact that the CCA was enacted in 2013, it was only put into force in January 2014 due the necessity to edit further guidelines. This time gap was used by the Comptroller General Office to prepare internal regulations and rules such as how a procedure would be conduct or which kind of compliance mechanisms are mandatory in order to reduce sanctions. The guidelines were ready in January 2014 but the 
president of Brazil did not sign this regulation in 2014. Dilma Rousseff, who in 2014 was running for re-election, did not issue the decree in that year in order to avoid any doubts or courts disputes, even after a corruption investigation involving Petrobras, the biggest Brazilian state-controlled company, was opened.

In March 2014, Brazil saw the beginning of another huge corruption scandal being brought to public attention. Dubbed 'Car Wash' (Lava Jato in Portuguese), it is the bribery, kickback and federal public money laundering investigation resulting in a rare case of effective cooperation between the Federal Police, the Federal Prosecutor Service and the Federal Judiciary (De Figueiredo, 2015). The scheme seems to be old-fashion as politicians and political parties made it an aim to appoint top Petrobras officials who colluded with a cartel of private companies to overcharge contracts for construction and service work. The cartel, known as 'the club' by its own members, not only decided which of its member companies would win a contract but also split part of the oily company's payments with its officials, Congress members and leaders of political parties. Part of the money received through the overcharged contracts also went direct to political campaigns as legal donations.

Lava-Jato main findings have been making newspaper headlines every single day and the scope of this investigation is still rapidly expanding. Throughout an 18-month span, it has already investigated Petrobras' contracts and it has sent more than thirty executives from Brazil's top construction firms as well as former or non-elected politicians and high rank former civil servants into police custody. In addition, 47 members of the National Congress are already being investigated by the Supreme Court, making the petrolão (the "big oily") Brazil's biggest corruption scandal to date (De Figueiredo 2015).

During 2014, while the task force was investigating well-known companies and 
arresting their main executives, the brand new 'anti-corruption law' was not enforced a single time by the Comptroller General Office, who had the ability to either execute leniency agreements relating to conduct at federal level or to involve foreign governments. Only in December 2014, after several whistle-blowing agreements signed by these suspicious companies' bosses with external anti-corruption agencies, the Comptroller General decided to open internal administrative procedures against eight constructors. The executive anti-corruption agency awaited Dilma's re-election to start investigating the companies and, according to the Electoral Court reports, all made massive donations to her campaign.

Among the companies whose bosses and executives were being investigated, eight of them financed Dilma's re-election campaign and six of them financed the opposition candidate who ran against the president during the second round. Both candidates received around 98,800,000 reais (approximately $\$ 44 \mathrm{mi}$ ). These companies also made donations to other candidates as well as to political parties. The donations stopped after November when 24 top executives were arrested, according the Electoral Court data available online. During 2014, these companies donated around $45 \%$ of all the donations reported by the three main and biggest political parties in Brazil (PT, PSDB and PMDB). In addition, these same companies are also part of the major infrastructure contracts made by federal and local governments. They signed contracts that sum over 59 billion reais (\$28bi) with Petrobras. Nine of them that were being investigated were also paid 11.4 billion reais $(\$ 5.6 \mathrm{bi})$ by the Federal Executive branch between 2004 and 2014 (Contas Abertas 2014). (See Figure 1.) 
Figure 1 - Total payments from the Federal Executive branch to companies under investigation between 2004 and 2014 (in reais)

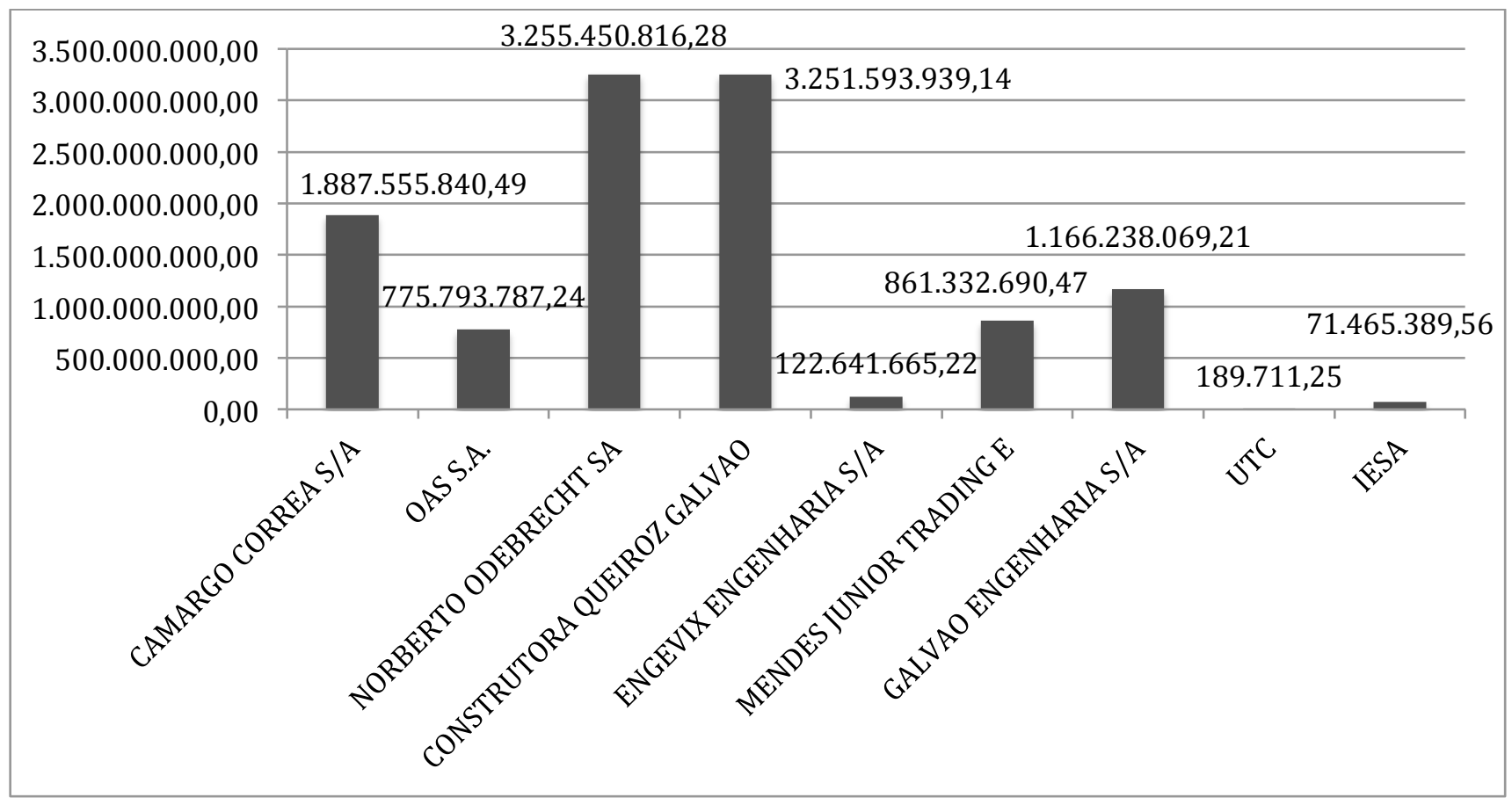

Sources: Contas Abertas/Portal da Transparência

During the campaign, other candidates made strong critiques against President Dilma Rousseff because she allowed space for this and, therefore, did not enforce the legislation properly. Even under attack, the president resisted to issue the guidelines and, therefore, Brazil was not prepared to properly enforce its CCA. The 'anticorruption law' had been enacted in January 2014, but the president only issued the decree in March 2015 as part of a series of anti-corruption measures to counter the increasing number of demonstrations focusing on her administration.

At the beginning of 2015, her television speeches were reverberating with the noise of clanging pots made by those against her. On the 15th of March, people went back to streets to protest against her and her administration. Three days later, Dilma Rousseff signed Decree No. 8,420/2015 further implementing Law No. 12846/2013 
setting guidelines for calculating fines, establishing rules to leniency agreements and criteria to Brazilian regulators use the companies' anti-corruption compliance programmes to reduce penalties.

After the Decree 77, four other guidelines were released by the Comptroller General Office, who detailed, for instance, not only the expected systems of internal controls but also all the steps to open a procedure and investigate companies as well as what the Federal government understands as gross revenues. In December 2015, a provisional Executive Order (MP 703) amended the Law and provided, among other things, a relief to companies signing leniency agreements in corruption cases all the while allowing them to pursue contracts with public administration. The Executive claimed $^{8}$ that the proposed changes were necessary to facilitate quicker administrative procedures, to foster economic activity, and to preserve jobs. At the same time, it made the sanctions less severe and it included other actors such as the account court and the prosecutor service as enforcers.

This 15-year 'anti-corruption law' process has received extensive media coverage questioning its slow progression as well as the content of the main provisions introduced by this new law. Current procedures that have opened against companies already under investigation by external anti-corruption agencies have also received attention. The media has also explored companies' suspicious relationships with politicians as financers or governmental contractors. And yet, no company has been

\footnotetext{
${ }^{7}$ See Portaria 909/2015 and 910/2015; Instrução Normativa 1/2015 and 2/2015 available at http://www.cgu.gov.br/noticias/2015/04/cgu-disciplina-procedimentos-para-processos-de-responsabilizacao-deempresas

${ }^{8}$ Ministers of cabinet of Justice, Finance, Comptroller General Office and Federal Attorney General. See document at http://www2.camara.leg.br/legin/fed/medpro/2015/medidaprovisoria-703-18-dezembro-2015-782125exposicaodemotivos-149094-pe.html
} 
punished, although there are 29 of them being preliminarily investigated and five leniency agreements requests addressed to the Comptroller General Office.

The Judiciary in this Lava-Jato case is convicting and applying criminal sanctions against businessmen at a faster rate than the Federal Executive branch and its administrative fines against their companies, contrary to the main efficiency argument which sustains that the Brazilian Act should only adopt only civil sanctions against corrupt companies. Therefore, it remains the question whether the 'anti-corruption law' needs another external push to bring out the first charges and sanctions, especially against those who are already being investigated by other anti-corruption agencies.

\section{Main provisions: Following international patterns except on enforcement}

Fifteen years after signing the OECD Convention, Brazil is struggling to enforce a legal instrument that makes companies strictly liable for acts of corruption (both domestic and foreign) and bid-rigging practised by their employees and agents. Although the Brazilian Clean Company Act was designed based on the main provisions of the UK Bribery Act and the US Foreign Corrupt Practices Act (FCPA), the Brazilian text only provides strict civil and administrative penalties but no criminal sanctions for companies as the OECD suggests and as the other two acts do as well. Therefore, imprisonment as a penalty is not expected for Brazil even though it will be enforcing this specific legislation.

Nevertheless, a brief comparison among the main provisions of the Brazilian, the UK and the US acts shows a similar conclusion previously pointed out by Zaheer (2014), who compared Law 12846/2013 with OECD Convention requirements. 'The Brazilian Law either meets or exceeds' the core international patterns, 'except those on 
De Figueiredo, Fernanda Odilla Vasconcellos. Building up a convenient accountability: How the 'anti-corruption' law in Brazil was put into force.

enforcement' (Zaheer 2014:18). Table 2 below compares 17 topics of FCPA, UK Bribery Act and the Brazilian CCA

Table 2 - Main provisions of FCPA, UK Bribery Act and the Brazilian Clean Company Act

\begin{tabular}{|c|c|c|c|}
\hline Main provisions & FCPA & UK Bribery Act & $\begin{array}{l}\text { Brazilian Clean Company } \\
\text { Act }\end{array}$ \\
\hline $\begin{array}{lrr}\begin{array}{l}\text { Offence } \\
\text { foreign } \\
\text { officials }\end{array} & \text { to } & \begin{array}{r}\text { bribe } \\
\text { (public) }\end{array} \\
\end{array}$ & Yes & Yes & Yes \\
\hline $\begin{array}{llr}\begin{array}{l}\text { Offence } \\
\text { national } \\
\text { officials }\end{array} & \text { to } & \begin{array}{r}\text { bribe } \\
\text { (public) }\end{array} \\
\end{array}$ & No & Yes & Yes \\
\hline $\begin{array}{l}\text { Extraterritorial } \\
\text { Jurisdiction }\end{array}$ & Yes & Yes & Yes \\
\hline Targets (Jurisdiction) & $\begin{array}{l}\text { U.S. companies and } \\
\text { citizens, foreign } \\
\text { companies listed on } \\
\text { U.S. stock exchange, or } \\
\text { any person acting } \\
\text { while in the U.S. }\end{array}$ & $\begin{array}{l}\text { Individuals who are UK } \\
\text { nationals or are } \\
\text { ordinarily resident in } \\
\text { the UK and } \\
\text { organizations that are } \\
\text { either established in the } \\
\text { UK or conduct some } \\
\text { part of their business in } \\
\text { the UK }\end{array}$ & $\begin{array}{l}\text { Corporations, partnerships, } \\
\text { and proprietorships, both } \\
\text { for-profit and non-profit. It } \\
\text { also subjects to its terms } \\
\text { non-Brazilian legal entities } \\
\text { that operate through an } \\
\text { office, branch, or } \\
\text { representation office in } \\
\text { Brazil, even if only } \\
\text { temporarily. }\end{array}$ \\
\hline $\begin{array}{l}\text { Private-to-private } \\
\text { bribery }\end{array}$ & Yes & No & No \\
\hline $\begin{array}{l}\text { Criminalise the } \\
\text { acceptance of a bribe }\end{array}$ & No & Yes & No \\
\hline $\begin{array}{l}\text { Active and passive } \\
\text { bribery }\end{array}$ & Only active & Yes & Only active \\
\hline $\begin{array}{l}\begin{array}{l}\text { Different acts } \\
\text { bribery }\end{array} \\
\end{array}$ & No & No & Yes \\
\hline Corrupt intent & Yes & No & No \\
\hline $\begin{array}{l}\text { Facilitation payments } \\
\text { and promotional } \\
\text { expenses (such } \\
\text { travel as } \\
\text { accommodation) }\end{array}$ & Yes & No & $\begin{array}{l}\text { No, although it still poses } \\
\text { controversies about which } \\
\text { kind of act is punishable. }\end{array}$ \\
\hline Criminal liability & Yes & Yes & $\mathrm{No}$ \\
\hline
\end{tabular}

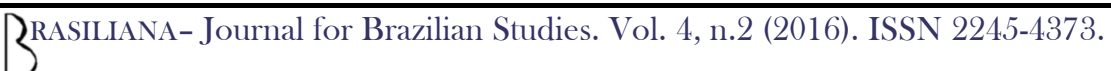


De Figueiredo, Fernanda Odilla Vasconcellos. Building up a convenient accountability: How the 'anti-corruption' law in Brazil was put into force.

\begin{tabular}{|c|c|c|c|}
\hline $\begin{array}{l}\text { Objective } \\
\text { responsibility }\end{array}$ & No & $\begin{array}{l}\text { Yes, for failure to } \\
\text { prevent bribery }\end{array}$ & Yes \\
\hline Fines & $\begin{array}{l}\text { An individual can be } \\
\text { fined up to US } \$ 250,000 \\
\text { per violation. For } \\
\text { companies, fine of up } \\
\text { to US } \$ 2,000,000 \text { per } \\
\text { violation. }\end{array}$ & Unlimited & $\begin{array}{l}\text { Up to } 20 \% \text { of the companies } \\
\text { gross revenue (the year } \\
\text { before the opening the } \\
\text { investigative procedure) or } \\
\text { up to } 60,000,000 \text { reais } \\
\text { (when it is not possible to } \\
\text { calculate the gross revenue) }\end{array}$ \\
\hline Other penalties & $\begin{array}{l}\text { An individual may be } \\
\text { given up to five years } \\
\text { imprisonment. For } \\
\text { companies, debarment } \\
\text { from Public } \\
\text { Procurement } \\
\text { Contracts }\end{array}$ & $\begin{array}{l}\text { Imprisonment for } \\
\text { individuals of a } \\
\text { maximum of } 10 \text { years. } \\
\text { For companies, } \\
\text { debarment from Public } \\
\text { Procurement Contracts }\end{array}$ & $\begin{array}{l}\text { Debarment from Public } \\
\text { Procurement Contracts. } \\
\text { Publish the conviction. } \\
\text { Dissolve a company in } \\
\text { particularly egregious cases }\end{array}$ \\
\hline $\begin{array}{l}\text { Plea Bargaining/Self } \\
\text { report of corrupting } \\
\text { practices }\end{array}$ & Yes & Limited & $\begin{array}{l}\text { Yes, it minimizes the fines } \\
\text { in } 2 \%\end{array}$ \\
\hline $\begin{array}{l}\text { Though penalties for } \\
\text { faltering to maintain } \\
\text { adequate systems of } \\
\text { internal controls }\end{array}$ & Yes & Yes & $\begin{array}{l}\text { Yes. Efficient compliance } \\
\text { mechanism minimizes the } \\
\text { fines from } 1 \% \text { to } 4 \%\end{array}$ \\
\hline Who enforces the Act & $\begin{array}{l}\text { Both civil and criminal } \\
\text { proceedings can be } \\
\text { brought by DOJ and } \\
\text { SEC }\end{array}$ & $\begin{array}{l}\text { Both civil and criminal } \\
\text { proceedings by Serious } \\
\text { Fraud Office (SFO) }\end{array}$ & $\begin{array}{l}\text { The Comptroller General } \\
\text { Office (CGU) for } \\
\text { administrative procedures } \\
\text { in the international sphere. } \\
\text { I the Federal sphere all } \\
\text { ministries and also CGU. } \\
\text { Prosecutor Service can also } \\
\text { act in courts to civil } \\
\text { procedures. Every state and } \\
\text { municipality can also } \\
\text { enforce the law when it } \\
\text { involves local civil } \\
\text { servants. }\end{array}$ \\
\hline
\end{tabular}

Sources: FCPA, UK Bribery Act, Law 12846/2012, Decree 8420/2015; CGU, Transparency International (http://www.transparency-usa.org/documents/FCPAvsBriberyAct.pdf)

3RASILIANA- Journal for Brazilian Studies. Vol. 4, n.2 (2016). ISSN 2245-4373. 
Unlike the US FCPA, Table 2 shows that both Brazilian and British acts do not punish private to private bribes. In addition, both Brazilian and British ones require no proof of top bosses' knowledge or the intent of any benefits achieved through an illegal act against the public administration committed by any employee, even through a subsidiary or a subcontractor. Unlike the UK Bribery Act, the Brazilian and the US acts do not criminalize the acceptance of a bribe, although Brazil has other laws that do it. Moreover, both Brazilian and US ones take on the role of being both an investigator and prosecutor with one only agency.

Table 2 also helps visualize who should enforce the acts in the three countries. In the case of Brazil, they are slightly different from the US and UK acts. To be the enforcer, the Comptroller General Office was chosen to coordinate and, in special occasions, to conduce administrative investigations in Brazil's federal sphere. The agency is also expected to conduce all the leniency agreements at federal levels as well as all the overseas cases.

In fact, in Brazil, even in the Federal sphere, the task to investigate companies for suspicious or corrupt acts within Brazilian territory is given to the Comptroller General, the Prosecutor Service and the Federal Government Attorney General Service and each one of the 39 ministries. The Comptroller General officers, however, cannot take cases to court. In order to ensure civil sanctions, such as dissolving a company or seizing revenue or property, it is expected that the Prosecutor Service, which is an external anticorruption agency, or the Federal Government Attorney Service representatives take the cases to court. However, it still remains unclear whether and how the administrative procedures will be shared with other law enforcement authorities (Zaheer 2014). In addition, according to the Act, any local authority in the 27 states as well as in the 5670 
municipalities in Brazil can enforce the Act, although most of them have hardly any internal agencies prepared to enforce any anti-corruption laws.

From December 2014 to April 2015, the Comptroller General Office opened investigative procedures against 29 companies and registered only five requests of leniency agreements being analysed by an already overwhelmed anti-corruption agency of the Federal government, which was selected to enforce the new Act in the federal and international spheres with no extra budget. None of them reached in any administrative outcome though to date. In addition, in May the interim President of Brazil Michel Temer decided to disband the Comptroller General Office and created instead the Ministry of Accountability, Transparency and Control through an Executive Order (MP 726/2016). All of the Comptroller General Office's attributions were transferred to the new agency.

Created in 2001 and renamed in 2003 with additional tasks, the Comptroller General Office is one of the Federal Executive branch internal control agencies. It carries out all the public audits, corruption prevention and ombudsman activities as well as being responsible for supervising all internal investigations against the government's civil servants. Before announcing his resignation in December 2014, the former minister (head of the agency) complained about budget cuts suggesting such cuts has made it harder for the agency to fulfil its anti-corruption mission. After the new task regarding the CCA, the anti-corruption agency suffered another cut that affected the federal administration as a whole. In the case of the anti-corruption agency, the cut per month is 1.89 million reais (\$ 0.7 million).

On the other hand, in line with both acts as well as with OECD guidelines, the Brazilian act gives weight to generally effective compliance programmes in order to minimise sanctions. Unlike either, however, it exceeds the main international 
frameworks allowing courts to dissolve a company in particularly egregious cases and at the same time it does not include the prohibition to sign new contracts while a company is being investigated or offering a leniency agreement among its provisions (Magalhães 2013).

Brazilian legislation also includes other serious and complex fraud issues other than bribery. Nevertheless, even inside the Comptroller General Office, there are still controversies around which act is punishable, considering that the five topics listed as offences on written Law can be considered imprecise. It is not clear, for instance, what will be considered 'undue pecuniary or other undue advantage' as it says Chapter 2 of the Brazilian CCA. In comparison, the US Act does not punish, for instance, facilitation payments and promotional expenses such as travel or accommodation costs, in contrary to the UK Act that consider them an offence.

Although there are some gaps or issues to be addressed, on paper the Brazilian CCA attends international demands without being a copy of international frameworks. It was customised with its own peculiarities. However, it is not clear yet how it will be enforced, especially by state and municipalities agencies.

\section{Convenient accountability: A reaction to intense pressure}

Like any new legislation, there was not enough time for the courts to decide on the most controversial topics of the CCA. Further regulations and guidelines are also expected to be introduced. However, the long and slow process of preparing, designing and implementing guidelines around the Act can be seen as a clear sign that Brazil has made the obvious choice to not ignore civil society's claims and neither to rush and improve systems that could punish, for instance, the major campaign financers and contractors in 
the country. This apparent 'lack of rush' might be understood as an attempt to adopt the less controlled systems under the rulers perspective, at least in the short term.

There is a real concern inside the Federal government around the effects of applying a severe punishment, such as the dissolution of companies, as the outcome of any current enquires. It is important to note that will be punished only those acts of corruption committed after January 2014, when the CCA was officially put into force. As mentioned previously, the first targets of Law 12846/2013 are those who offered leniency agreements or are already being investigated and have a close relationship with high level politicians not only as traditional campaign financers but also because they are responsible for the biggest and most important infrastructure contracts in Brazil. Therefore, the federal government cannot take any chance to be dysfunctional or to place an economy that has already been considered as disappointing in further risk (The Economist 2015).

When governmental rulers take baby steps to design, approve, enforce and regulate a new legislation, they could be, to some extent, calculating all the risks to avoid less campaign donations and also massive unemployment and bankruptcy of major companies. At the same time, they are taking into account the necessity to take action against international constraints and pressure as well as to the peoples' claims for better anti-corruption mechanisms. It is, therefore, a convenient reaction that seems to be suitable and as comfortable as possible for those who are in power; it is a compressible movement to respond to different kind of pressures. This is labelled here as 'convenient accountability' and occurs when rulers or state agents do want to avoid disappointment among opposing interests and, therefore, take the most convenient measures for them. Indeed, it is a decision based on self-interest and is made in order to ensure power stability. 
The suggestion that arises from this study is to apply a rationality perspective to both those who have criminal (or corrupt) behaviour and those supposed to enforce laws and follow internal rules. Gary Becker in his article 'Crime and Punishment: an economic approach' (1968) suggests that crime can be seen as a choice based on costbenefit analysis in order to maximise profits and minimise losses (De Figueiredo 2012).

In the case of the Brazilian CCA, this cost-benefit analysis can be identified in almost the whole process from the beginning. It important to note that in this specific case, the 'convenient accountability' concept applies to the attempt to find a balance between the expected improvement of Brazil's horizontal accountability and vertical accountability, especially because the accountable target states in the interface between the public and the private sectors. Moreover, when horizontal accountability targets private companies, as is the case of Law 12846/2013, it is more likely to expect the 'convenient accountability' due to the different kinds of pressure and interests handled by rulers who do want to remain in power and want to avoid frustrating the maximum number of direct and indirect supporters.

Furthermore, as O'Donnell (2004) points out, horizontal accountability happens when state institutions act to prevent, redress or punish the presumably illegal actions (or inactions) and its degree of efficiency varies across cases and time periods. 'Horizontally, in a democratic legal system no state institutions or officers are supposed to escape from legal controls regarding the lawfulness of their actions' ( $\mathrm{O}^{\prime}$ Donnell 2004:37). Although vertical (or electoral) accountability, by definition, exists in a democracy (O'Donnell 1998, 1999 and 2004), it is important to note that its weight can be affected by the results of both horizontal and societal accountabilities. Electoral results, for instance, can be different depending on how a government improves and show the results of its anti-corruption agencies. What is here called 'convenient accountability' is 
the perfect point of convergence or the precise weight of O'Donnell's ideal labels as well as of other intermediate categories, such as 'diagonal' or 'oblique' (Bovens 2007) or celestial accountability (Sklar 1999) in order to attend powerholders' main interests

There is evidence that the Law 12846/2013 case was an attempt to create new legislation and enforce it to see to the pressure that came from the streets, media and ballots without transforming this process into an open crusade against important campaigners or private partners. The powerholders, both in the Federal Executive branch and in the Legislative, tried to keep the balance among intense pressure. In sum, the CCA 15-year process can be seen as a calculated action based on cost and benefit analysis that might have resulted in insufficient disincentives for engaging in offences such as bribery by companies, but not exactly immediately and possibly neither in a short period of time.

It is essential to highlight that having a specific law does not mean less accountability or crime control, especially in countries like Brazil in which some laws are famous for not sticking. Correct enforcement followed by real sanctions may be considered indispensable. Therefore, more important than the rule of the law is the 'risk of apprehension, the seriousness of the expected punishment, the value of the criminal enterprise, and his or her immediate need for criminal gain' (Siegel 1992:131). 'Hence, crime is more likely to be controlled if, for instance, more law enforcement and punishment is applied' (De Figueiredo 2012:15).

On the other hand, it is possible to note that until now the main, visible and positive outcome of this new law came from some companies that are operating in order to improve or create compliance mechanisms (Bottini and Tamasauskas 2014) as a preventive act. Indeed, international and local companies are expected by the CCA to maintain not only adequate systems of internal controls but also to be ready to self- 
report corrupt practices in order to minimise sanctions in case they are caught.

As Nobrega (2014) points out, the new rules, if enforced, can be considered able to modify the behaviour of companies involved in corrupt practices. 'However, for effective change in behaviour, the perception that those rules are in fact being applied is necessary. Therefore, skilled civil servants as well as appropriate procedures and punishments along with low reversibility of administrative decisions in the judicial environment are elements to be sought by the government' (Nobrega 2014:71).

\section{Final thoughts}

Until now, there have been no clear signs that would allow us to predict the real outcomes of the enforcement in the federal and (even less) in the local spheres. Future studies should look for evidence to show whether 'convenient accountability' could affect the decision of opening new enquiries and punishing companies as well as how long already opened procedures are taking to be completed. At the same time, whether another public street demonstration or any international embarrassment could force the Comptroller General Office to rush its internal investigation and announce sanctions in the near future remains a question which is open to debate.

Despite the apparent force of civil society in this case of 'pressure from below' driving every step of this legislation, no company has yet been punished under Law $12846 / 2013$. The same 'lack of rush' to design and put this law into force can be seen during the guideline phase as well as during the initial enforcement phase along with the investigative enquires and leniency agreements being conducted slowly. This can be seen if compared with the outcomes of Lava Jato investigation conducted by the Federal Police, Prosecutor Service and the federal judiciary. 
In addition, before concluding the ongoing investigations, however, the Federal Executive preferred to change the Law in order to attend some companies' demands, especially to allow them to sign contracts with the public service after signing leniency agreements. The provisional Executive Order 703/2015 has the full force of Law for 90 days and, then, it needs to be validated by the National Congress. There are already attempts to make amendments in order to directly connect the anti-corruption Law to other anti-corruption agencies in the Brazilian multi-institutional accountability system such as the prosecutor service and the account court (De Figueiredo 2016).

In conclusion, how anti-corruption laws are designed and put into force matters and affects their enforcement, especially in countries such as Brazil where political-will is affected by the inevitable pressure of those who do not want greater control mechanisms. Hence, Brazil's Clean Company Act can be considered nothing else but an example of 'convenient accountability'.

\section{Bibliography}

Beccaria, C. (1963), An Essay on Crimes and Punishments. Indianapolis: Bobbs-Merrill.

Becker, G. S. (1968), 'Crime and Punishment: An Economic Approach', The Journal of Political Economy, Vol. 76, No. 2. (Mar. - Apr., 1968), pp. 169-217.

Bottini, P. and Tamasauskas, I. (2014), 'A interpretação constitucional possível da responsabilidade objetiva na Lei Anticorrupção' in Revista dos Tribunais (São Paulo. Impresso), v. 974, p. 133, 2014.

Bovens, M. (2007), Analysing and assessing accountability: A conceptual framework. European Law Journal, 13(4): 447-468.

Contas Abertas. (2014), 'Empresas da Lava Jato receberam $\mathrm{R} \$ 11,4$ bi do governo federal de 2004 a 2014 [Companies investigated by "Lava Jato" gained $R \$ 11,4$ bi from the 
federal government from 2004 and 2014] at http://www.contasabertas.com.br/website/arquivos/10024. Accessed on the 6th of August 2014.

De Figueiredo, F.O. (2012), Big Fish Out of Water: The Unequal Fight Against Political Corruption in Brazil. MA Dissertation in Criminology and Criminal Justice/King's College London.

. (2015), 'Suit Up to Go to Jail: How the Multi-institutional Approach Against Corruption Can Work In Brazil' in King's College Political Science Dialogue magazine. Issue 11, spring 2015. Available on http://issuu.com/kcldialogue/docs/issue_11_online/1.

. (2016), 'Building accountability under intense pressure: Lessons from the 'anti-corruption' legislation in Brazil' Global Rule of Law Exchange Practice Notes, Bingham Centre for the Rule of Law, London, 2016.

Falcão, M. (2010), 'Lula envia ao Congresso projeto de lei que pune empresas que pratiquem atos de corrupção [Lula sends to Congress bill that punishes companies for corruption acts' in Folha de S.Paulo http://www1.folha.uol.com.br/poder/2010/02/691308-lula-envia-ao-congresso-projetoque-pune-empresas-que-pratiquem-atos-de-corrupcao.shtml. Accessed on the 4th of August 2014.

Koehler, M. (2014), The Foreign Corrupt Practices Act in a New Era. Cheltenham Glos Edward Elgar Publishing Ltd.

Lei No. L12846 [Brazilian Clean Companies Act, Chapter 1, Art 1, Chapter 2, Art 5], de 1 de Agosto de 2013, DIARIO OFICIAL DA UNIAO [D.O.U] de 2.8.2013 (Braz.), available at http://www.planalto.gov .br/ccivil_03/_Ato2011- 014/2013/Lei/L12846.htm (English Translation).

Levine, Andrew M., Yannett, Bruce E., Gomes de Almeida, Renata Muzzi., Michaels, Steven S. and Frischtak, Ana L. (2013), 'Brazil Enacts Long-Pending Anti-Corruption $\begin{array}{lllllll}\text { Legislation' } & \text { FCPA } & \text { Update } \mathrm{n} & \text { Vol. } & 5, & \text { No. } & 1\end{array}$ http://www.debevoise.com/ /media/files/insights/publications/2013/08/fcpa\%20update/f iles/view\%20fсpa\%20update/fileattachment/fcpa_update_aug2013_111213pdf.pdf 
Magalhães, João Marcelo Rego (2013) Aspectos relevantes da lei anticorrupção empresarial brasileira (Lei $\mathrm{n}^{\mathrm{o}}$ 12.846/2013) [Relevant features from Brazilian corporate corruption law (Law 12.846/2013)] in Revista Controle - Doutrina e Artigos Volume XI № 2 http://www.tcm.rj.gov.br/Noticias/11280/controle_cmpleta_2013_2.pdf\#page=26.

Nascimento, M.D. (2014), Lei anticorrupção empresarial: aspectos críticos à Lei $n^{\underline{o}}$ 18.846/2013. Belo Horizonte: Fórum, v. 13, 2014, p. 15.

Newton, I. (1999), The Principia: Mathematical Principles of Natural Philosophy, a new translation by I. Bernard Cohen and Anne Whitman. Berkeley: University of California Press.

Nobrega, A.C.V. (2014), ‘A Nova Lei de Responsabilização de Pessoas Jurídicas como Estrutura de Incentivos aos Agentes [The New Anticorruption Act as an Incentive To Agents]' in Economic Analysis of Law Review EALR, V. 5, no 1, p. 62-76, Jan-Jun, 2014.

O'Donnell, G. (1998), "Horizontal Accountability in New Democracies" in Journal of Democracy 9.3 (1998) 112-126.

. (1999), 'Delegative Democracy' in G. O'Donnell Counterpoints: Selected Essays on Authoritarianism and Democratization. Notre Dame, University of Notre Dame Press: 159-174.

. (2004), 'Why the Rule of Law Matters' in Journal of Democracy. Volume 15, Issue $4, \mathrm{pp}-32-46$.

Schedler, A. (1999), 'Conceptualizing Accountability' The Self-Restraining State: Power and Accountability in New Democracies. Ed. Andreas Schedler, Larry Diamond, and Marc F. Plattner. Boulder and London: Lynne Rienner Publishers, 1999. 13-28.

Senado. (2013), 'Senado aprova punição a empresas por corrupção [Senate approves punishment against companies for corruption acts]' in http://www12.senado.leg.br/noticias/materias/2013/07/04/senado-aprova-punicao-aempresas-por-corrupcao Accessed on the 5th August 2015.

Siegel, L. (1992), Criminology. Saint Paul (Minnesota): West Publishing Company 
Singer, A. (2013), 'Brasil, junho de 2013: Classes e ideologias cruzadas [Brazil, June 2013: Classes and cross ideologies]' in Novos Estudos CEBRAP, no.97. São Paulo, November 2013

Skar, R. L. (1999), 'Democracy and Constitutionalism' in The Self-Restraining State: Power and Accountability in New Democracies. Ed. Andreas Schedler, Larry Diamond, and Marc F. Plattner. Boulder and London: Lynne Rienner Publishers, 1999. 13-28.

The Economist. (2015), Brazilian waxing and waning. Jun 5th 2015. http://www.economist.com/blogs/graphicdetail/2015/03/economic-backgrounder Accessed on the 5th of August.

US Dep't of Justice and US Securities and Exchange Comm'n, "A Resource Guide to the U.S. Foreign Corrupt Practices Act" (Nov. 2012) at 56-66, http://www.justice.gov/criminal/fraud/fcpa/guidance/. 7 See UK Min. of Justice, "The Bribery Act 2010: Guidance" (Mar. 2011) at 20.

Zaheer, S. (2014), 'Brazil's Landmark Clean Companies Act: Comparison to the OECD Anti-Bribery Convention and Issues' in Pacific McGeorge Global Business \& Development Law Journal. March 1, 2014. Available at http://ssrn.com/abstract=2417155 or: http://dx.doi.org/10.2139/ssrn.2417155. 